\section{Nitrogen Rates Effects on the Yield, Nutritional Status, Fruit Quality, and Profitability of Tomato Grown in the Spring with Subsurface Irrigation}

\author{
Monica Ozores-Hampton ${ }^{1}$ \\ University of Florida, Institute of Food and Agricultural Sciences, South \\ West Florida Research and Education Center, 2685 State Road 29 North, \\ Immokalee, FL 34142
}

\section{Eric Simonne}

University of Florida, Institute of Food and Agricultural Sciences, Horticultural Sciences Department, Gainesville, FL 32611

Fritz Roka and Kelly Morgan
University of Florida, Institute of Food and Agricultural Sciences, South West Florida
Research and Education Center, 2685 State Road 29 North, Immokalee, FL 34142

Steven Sargent

University of Florida, Institute of Food and Agricultural Sciences, Horticultural Sciences Department, Gainesville, FL 32611

Crystal Snodgrass

Manatee County Extension Service, Palmetto, FL 34221

Eugene McAvoy

Hendry County Extension Service, LaBelle, FL 33935

Additional index words. Solanum lycopersicon, best management practice (BMP), seepage irrigation, sandy soils, nutrient management

\begin{abstract}
With increasing environmental concerns, the sharp cost increase of fertilizer and the absence of a soil test to predict nitrogen (N) needs of tomato (Solanum lycopersicon $\mathrm{L}_{\text {.) }}$ grown on Florida's sandy soils, a partnership was created with growers, state agencies, and the University of Florida, Institution of Food and Agricultural Sciences (UF/IFAS). The objectives of this study were to identify a range of $\mathrm{N}$ rates that would result in highest yields and postharvest quality, and maximum economical return for tomato, grown with subsurface irrigation (management of a perched water table above an impermeable soil layer or hard pan) during the spring season (low probability of leaching rain events). The study was conducted in Spring 2007 and 2008 in Palmetto, FL, with N rates ranging from 22 to $470 \mathrm{~kg} \cdot \mathrm{ha}^{-1}$ at pre-plant as ammonium nitrate $\left(\mathrm{NH}_{4} \mathrm{NO}_{3}\right)$. Weather conditions were typical of a dry spring season in central Florida with no leaching rain events recorded in either year; however, rain patterns were different between the 2 years. In the absence of leaching rain and frost protection (either may raise the water table), petiole sap $\mathrm{NO}_{3}-\mathrm{N}$ decreased over time and the rate of decline depended on the $\mathrm{N}$ fertilizer rate. Extra-large and total marketable fruits yields showed a quadratic plateau response to $\mathbf{N}$ rates with maximum yields at two harvests ( $97 \%$ of the yields) grown with 172 and $298 \mathrm{~kg} \mathrm{~N} / \mathrm{ha}$ in 2007 and 2008, respectively. During subsequent ripening, $N$ rate did not correlate consistently to fruit ripening rate, fruit firmness, nor compositional quality at table-ripe stage. The high value of tomatoes relative to the cost of $\mathrm{N}$ fertilizer created a situation in which the profit-maximizing rate of $\mathbf{N}$ was not significantly different from the production-maximizing $\mathbf{N}$ rate. Whether the profitmaximizing level of $\mathbf{N}$ was higher or lower than the UF/IFAS-recommended rate depended on the growing season. With favorable growing conditions (i.e., conditions in 2008), a grower's net return would have decreased between $\$ 1000$ and $\$ 2000$ per hectare by using UF/IFASrecommended rates depending on market conditions. However, if the UF/IFAS-recommended rate of $224 \mathrm{~kg} \cdot \mathrm{ha}^{-1}$ resulted in the highest yield, applying upwards of $300 \mathrm{~kg} \cdot \mathrm{ha}^{-1}$ would have increased grower production costs by at least $\$ 67 / \mathrm{ha}$. Although fertilizer costs are known before the crop is grown, tomato prices are realized only at the end of the growing season and profit margins can only be calculated after the fact.
\end{abstract}

Received for publication 23 Aug. 2011. Accepted for publication 23 Feb. 2012.

${ }^{1}$ To whom reprint requests should be addressed; e-mail ozores@ufl.edu.
2009). Subsurface irrigation ("seepage irrigation") consists of managing a perched water table above an impermeable soil layer (hard pan) located at the 90 to $150 \mathrm{~cm}$ depth. Ground water is pumped into canals or ditches, then moves horizontally between two adjacent ditches (spaced 25 to $35 \mathrm{~m}$ ). When the water fronts from two adjacent ditches meet, the water table rises, thereby irrigating the crop from the hard pan up. This system also allows the raising of the water table to near the soil surface as a frost protection measure (OzoresHampton et al., 2010).

The length of the tomato growing season is 18,20 , and 16 weeks for fall, winter, and spring, respectively. The spring planting seasons are typically drier $(67.6 \mathrm{~mm} /$ month $)$ than the fall seasons $(103.8 \mathrm{~mm} / \mathrm{month})$ (Fraisse et al., 2010; Ozores-Hampton et al., 2006). Therefore, the risk of temporary flooding and nutrient loss from sandy soils is greater in fall seasons because of the increased risk of leaching rainfall. Leaching rain is defined as $76 \mathrm{~mm}$ in $3 \mathrm{~d}$ or $102 \mathrm{~mm}$ in $7 \mathrm{~d}$ for tomatoes (Olson et al., 2010).

Current irrigation recommendations for tomato grown in Florida consist of maintaining the water table between the 30 and $45 \mathrm{~cm}$ depth during plant establishment and then at the 45 to $60 \mathrm{~cm}$ depth thereafter as measured in shallow observation wells scattered in the field (Olson et al., 2010). Current fertilization recommendations for tomato grown in Florida are based on the results of Mehlich 1 soil test for phosphorus $(\mathrm{P})$, potassium $(\mathrm{K})$, calcium, magnesium, and micronutrients. For tomato planted on $1.8-\mathrm{m}$ centers $(1 \mathrm{ha}=5556$ linear $\mathrm{m}$ of row), the $\mathrm{N}$ recommendation is $224 \mathrm{~kg} \cdot \mathrm{ha}^{-1}$ for all planting seasons, tomato cultivars, soil, and irrigation types (Olson et al., 2010). Supplemental fertilizer applications are allowed after a leaching rain or when "low" nutrient levels are reported by foliar analysis or petiole sap testing or during extended harvest seasons (Hochmuth and Cordasco, 2008; Olson et al., 2010). When seepage irrigation is used, fertilizers are applied pre-planting as a "bottom mix" broadcast incorporated in the bed with $10 \%$ to $20 \%$ of the $\mathrm{N}$ and $\mathrm{K}$ and $100 \%$ of the $\mathrm{P}$ and micronutrients and as a "hot mix" consisting of the remaining $\mathrm{N}$ and $\mathrm{K}$ banded in two grooves located $\approx 5$ to $10 \mathrm{~cm}$ away from each bed shoulder (Olson et al., 2010). As water moves upward into the bed by capillarity, nutrients are slowly dissolved and made available for plant uptake (Sato et al., 2009). This system is called the nutrient gradient system (Geraldson and Whisenant, 1993).

Tomato growers typically follow irrigation recommendations, but they tend to use fertilizer rates above these recommended ones (Cantliffe et al., 2006). Numerous studies reported that extra fertilizer application can be justified in conditions such as temporary water table rises during heavy rainfall periods and/or for frost protection events, different lengths of growing season or with the use of vigorous hybrid varieties, and/or denitrifing conditions typical under seepage irrigation in southwest Florida (Simonne and Ozores-Hampton, 2006). 
Growers report that the practice of applying supplemental fertilizer once plants expressed "low" nutrient status does not facilitate full recovery, but results in reduced yields and increases cost as a result of the additional trips in the field. Of the $\mathrm{N}$ rate studies used to develop current fertilizer recommendations, only two multiple $\mathrm{N}$ rate studies with subsurface irrigation were conducted in Florida by Everett (1976) and Hochmuth et al. (1989) . The limitations of one study was the narrow $\mathrm{N}$ rate considered (180 to $450 \mathrm{~kg} \cdot \mathrm{ha}^{-1}$ ) and in both studies tomato yields were lower than currently experienced by the industry ( 8.7 to 21.7 $\mathrm{Mg} \cdot \mathrm{ha}^{-1}$ ).

Cultural practices, including fertilization and irrigation in 2012, must account for productivity and protection of natural resources. Growers should know their optimal fertilization rates and regulators should know the potential yield and economic consequences if reduced fertilizer rates are required. As a response to the Federal Total Maximum Daily Load mandate described in the Federal Clean Water Act (U.S. Environmental Protection Agency, 2010), the Florida legislature passed the Florida Watershed Restoration Act (Florida Senate, 1999), which gave the Florida Department of Agriculture and Consumer Services (FDACS) the authority to develop Best Management Practices (BMPs). Adopted by reference in rule $5 \mathrm{M}-8$ of the Florida Administrative Code, the "Water quality/quantity best management practices for Florida vegetable and agronomic crops" is the document that describes the BMPs that apply to vegetable crops in Florida (FDACS, 2006). Because the manual recognizes UF/IFAS production recommendations as the base for fertilization practices, it is essential that these recommendations are science-based and flexible to be trusted by the scientific community and widely adopted by the vegetable industry (Simonne et al., 2009).

The goal of this project was to determinate the $\mathrm{N}$ rates that would result in the highest yield, greatest postharvest attributes, and highest economical return for tomato with subsurface irrigation during the spring season. Therefore, the objectives of the study were to 1) evaluate the effect of spring $N$ fertilizer rates with seepage-irrigated tomato on plant nutritional status, marketable yield and distribution, and post-harvest quality; and 2) determine the economically optimal rate of $\mathrm{N}$ fertilization and analyze the sensitivity of $\mathrm{N}$ application rates to market conditions, specifically the price of tomatoes and cost of $\mathrm{N}$ fertilizers.

\section{Materials and Methods}

Two fertilizer trials were conducted in the spring of 2007 and 2008 on a commercial tomato farm near Palmetto, FL (lat. 27 $31^{\prime} 16^{\prime \prime}$ $\mathrm{N}$, long. $82^{\circ} 34^{\prime} 21^{\prime \prime} \mathrm{W}$ ). The soil at the field was an EauGallie fine sand with an organic matter content $(\mathrm{OM})$ of $2.0 \%$, which was slightly higher than the typical less than $1 \%$ OM content of most cultivated Florida sandy soils. In this field, an irrigation ditch was placed every three beds. In mid-January, the soil was rototilled and the "bottom mix" was applied at a rate of 22,88 , and $37 \mathrm{~kg} \cdot \mathrm{ha}^{-1}$ of $\mathrm{N}, \mathrm{P}$, and $\mathrm{K}$, respectively. The entire field received the same $22 \mathrm{~kg} \cdot \mathrm{ha}^{-1} \mathrm{~N}$ rate in the "bottom mix." On the same day, $80-\mathrm{cm}$ wide, 20 -cm tall beds were formed on $1.8-\mathrm{m}$ centers. Nitrogen fertilizer treatments were applied manually by placing $\mathrm{NH}_{4} \mathrm{NO}_{3}$ (ammonium nitrate) in $60-\mathrm{cm}$ long sections of $5-\mathrm{cm}$ diameter polyvinyl chloride (PVC) pipes cut in half and poring the fertilizer into the two grooves made in the soil on the bed shoulders (banded fertilizer). This method proposed by the grower cooperator ensured that each plant (transplants were set later at a within-row spacing of $60 \mathrm{~cm}$ ) was receiving exactly the prescribed fertilizer treatment. The remaining $\mathrm{K}$ was similarly applied manually to the grooves using potassium sulfate $\left(\mathrm{K}_{2} \mathrm{SO}_{4}\right)$ at a rate of $442 \mathrm{~kg} \cdot \mathrm{ha}^{-1}$ of $\mathrm{K}$ in all the plots. Hence, total K rate applied ("bottom mix" + banded fertilizer) was $475 \mathrm{~kg} \cdot \mathrm{ha}^{-1}$, which is a typical rate used in commercial production. After fertilizer application, the beds were fumigated with methyl bromide and chloropicrin $(67: 33$, $\mathrm{w}: \mathrm{w})$ at the rate of $336 \mathrm{~kg} \cdot \mathrm{ha}^{-1}$. The position of the shanks used to inject the fumigant did not affect the integrity of the fertilizer bands. All beds were covered with low-density black polyethylene mulch immediately after the fumigant application. The experimental design was a randomized complete block design with four and three replications in 2007 and 2008, respectively. Plots were $6 \mathrm{~m}$ long and included three adjacent beds (from ditch to ditch). The eight $\mathrm{N}$ fertilization treatments applied as the banded fertilizer $\mathrm{N}$ were 0,45 , 112, 179, 247, 314, 381, and $448 \mathrm{~kg} \cdot \mathrm{ha}^{-1}$. Because $22 \mathrm{~kg} \cdot \mathrm{ha}^{-1}$ was already present in the "bottom mix," total N rates were 22, 67, 134, 202, 269, 336, 403, and $470 \mathrm{~kg} \cdot \mathrm{ha}^{-1}$. On 15 Feb. 2007 and 5 Feb. 2008, 6-week-old 'Florida 47' tomato transplants (Seminis Seeds, Oxnard, CA) were established in the field in one row per bed, which created a plant population of 9258 plants/ha. Pest control measures followed UF/IFAS recommendations based on weekly scouting reports (Olson et al., 2010).

Monitoring wells were constructed from 1.2-m long, 4-inch diameter PVC pipes screened at the bottom $20 \mathrm{~cm}$ (Smajstrla, 1997). A float was attached to one end of a 19-mm PVC pipe to serve as the water level indicator. Permanent marks were made every $25 \mathrm{~mm}$ to indicate the water table depth below the plastic mulch bed. Weekly observations of the water table depth were taken throughout the growing season in four wells installed in the field (one in each replication in the center bed). Beginning at first flower and until second harvest, six most recently fully mature leaves were collected every 2 weeks to determine concentrations of $\mathrm{NO}_{3}-\mathrm{N}$ in fresh petiole (with leaflets attached) sap using ion-specific electrodes (Cardy; Spectrum Technologies, Inc., Plainfield, IL; Olson et al., 2010; Studstill et al., 2006). Tomatoes were harvested three times each year (on 15 May, 29 May, and 12 June 2007, and 1 May, 15 May, and 29 May 2008) as typical of commercial production and from 6-m long, representative sections in the center bed. Marketable mature green and colored tomatoes were graded in the field according to U.S. Department of Agriculture (USDA) specifications for extra-large, large, and medium fruit categories (USDA, 1997).

Postharvest evaluations were performed at the first and second harvests each year. Immediately after harvest, large-sized tomatoes at the breaker/turning color stage were placed in labeled paper bags $(\mathrm{n}=10$ fruit/ plot) and transported to the UF/IFAS, Postharvest Horticulture Laboratory in Gainesville, FL, and held overnight at $20{ }^{\circ} \mathrm{C} / 85 \%$ relative humidity $(\mathrm{RH})$. The next day, four fruits per plot were stored at $20{ }^{\circ} \mathrm{C} / 85 \% \mathrm{RH}$ until they reached table-ripe stage, defined as the point beyond the red-ripe stage when the fruit yielded noticeably to moderate pressure applied with thumb and fingertips at the equatorial region. Once fruits reached tableripe stage, they were frozen in sealed poly bags at $-30{ }^{\circ} \mathrm{C}$. The frozen samples were later thawed and homogenized and then centrifuged at $15,000 \mathrm{~g}_{\mathrm{n}}$ for $20 \mathrm{~min}$ at $5{ }^{\circ} \mathrm{C}$. The supernatant was filtered through cheesecloth, and the filtrate was used to measure soluble solids content (SSC) using a Mark Abbe II digital refractometer (Model 10480; ReichertJung, Depew, NY) and $\mathrm{pH}$ and total titratable acidity (TTA) using an automatic titrimeter (Model 719S Titrino; Metrohm Analysis Ltd., Switzerland) by titration with $0.1 \mathrm{~N} \mathrm{NaOH}$ to an end point of $\mathrm{pH}$ 8.2. TTA was expressed as percent citric acid equivalent.

Weather data were obtained from a Florida Automated Weather Network station located $\approx 31 \mathrm{~km}$ from the experimental field at the UF/IFAS, Gulf Coast Research and Education Center in Balm, FL. Petiole sap $\mathrm{NO}_{3}-\mathrm{N}$ concentrations data were analyzed using analysis of variance and means were separated by Duncan multiple range test $(P \leq 0.05)$. Changes in SSC, pH, and TTA levels in response to N rates were analyzed using regression analysis (SAS Version 9.1; SAS Institute Inc., Cary, NC). A yield response function $[f(X)]$, which measured the change in crop yield with a corresponding change in the $\mathrm{N}$ rate, was estimated by using four response models: the polynomial functions included a linear $(y=a+b \mathrm{X})$ and quadratic models $\left(y=a+b \mathrm{X}+c \mathrm{X}^{2}\right)$ where $y$ is the tomato yield and $\mathrm{X}=\mathrm{N}$ rate added fertilizer and $a, b$, and $c$ are constants (Black, 1993). The segmented functions included the linear plateau $(y=a+b \mathrm{X}$ if $\mathrm{X}<\mathrm{N}$ critical rate, $y=$ plateau yield if $\mathrm{X}>\mathrm{N}$ critical rate) and quadratic plateau $\left(y=a+b \mathrm{X}+c \mathrm{X}^{2}\right.$ if $\mathrm{X}<$ $\mathrm{N}$ critical rate, $y=$ plateau yield if $\mathrm{X}>\mathrm{N}$ critical rate) where $y$ is the tomato yield and $\mathrm{X}=\mathrm{N}$ rate added fertilizer and $a, b$, and $c$ are constants (Black, 1993). The functional form of the tomato yield response curve was assumed to be quadratic plateau based $P \leq$ 0.05 and the lowest mean square error (MSE). Maximum yields were determined at the intersection of the quadratic and plateau lines.

Economic analysis was based on the assumption that tomato growers are in business to maximize profits $(\pi)$ and will apply $\mathrm{N}$ 
fertilizer until the following profit equation reaches a maximum value:

$$
\pi=\left(P_{t} \times f(N)\right)-\left(C_{n} \times N\right)
$$

where $\mathrm{P}_{t}$ is the grower's price of tomatoes, $N$ is the amount of fertilizer, $f(N)$ is the yield response function with respect to $\mathrm{N}$ rate, and $C_{n}$ is the unit cost of $\mathrm{N}$. The $\mathrm{N}$ rate maximizing profit is obtained when the marginal product of $\mathrm{N}$ equals the ratio of input to output prices:

$$
\frac{\partial f(N)}{\partial N}=\frac{C_{n}}{P_{t}}
$$

Two market scenarios were analyzed to see how the maximizing profit $\mathrm{N}$ rate changed. Scenario (1) included an N price of $\$ 0.88 / \mathrm{kg}$ (price prevalent during the 2007 and 2008 seasons) and a tomato price of $\$ 10$ per $12.5-\mathrm{kg}$ carton. Prices of fresh market tomatoes can fluctuate widely during a season primarily as a result of supply disruptions. For example, south Florida shipping point prices averaged less than $\$ 10$ per carton in January 2011. By 15 Mar., prices had risen above \$24 per carton as a result of a major freeze in Mexico (USDA, 2011). A price of $\$ 10$ covered production costs but not all harvesting and selling costs (Van Sickle, 2011).

A second set of market conditions (Scenario 2) doubled the price of $\mathrm{N}$ fertilizer $(\$ 1.76 / \mathrm{kg})$ and reduced the price of tomatoes by $50 \%$ ( $\$ 5 /$ carton). Scenario 2 quadruples the price ratio $\left(\mathrm{C}_{\mathrm{n}} / \mathrm{P}_{\mathrm{t}}\right)$. An equivalent price ratio could have been achieved by holding tomato prices constant at $\$ 10$ and increasing $\mathrm{N}$ to $\$ 3.52 / \mathrm{kg}$. Although this article did not address the environmental fate of $\mathrm{N}$ lost to the ground and/or surface waters, economic analysis using a higher $\mathrm{N}$ price suggested that growers would have made more money even with higher fertilizer applications, but this is not to say higher fertilizer inputs are justifiable if the leaching potential is too great. Thus, the guidelines used to justify additional fertilizer $\mathrm{N}$ applications during the season must be quantified.

For each market scenario, the predicted yield from $\mathrm{N}$ rate maximizing profit was compared with the predicted yield resulting from applying $\mathrm{N}$ at the UF/IFAS-recommended rate of $224 \mathrm{~kg} \cdot \mathrm{ha}^{-1}$. The value of any yield differences between the UF/IFAS-recommended rate and $\mathrm{N}$ rate maximizing profit was determined by multiplying the predicted yield differences by the market price for each market scenario.

\section{Results and Discussion}

Weather conditions. Overall, weather data were normal from cold to warm and dry throughout the spring of 2007 and 2008 (Table $1)$. The maximum and minimum air temperatures were 30.9 and $7.9^{\circ} \mathrm{C}$ for 2007 and 31.3 and $11.5^{\circ} \mathrm{C}$ for 2008 , respectively. No freeze events occurred during 2007 or 2008 seasons. Rainfall totals in the 2007 and 2008 seasons were similar to historical averages with accumulations of 216 and $218 \mathrm{~mm}$, respectively. Because no qualifying leaching rain event

Table 1. Summary of maximum, minimum, and mean air temperature and historical mean rainfall during Spring 2007 and 2008 in central Florida. ${ }^{\mathrm{z}}$

\begin{tabular}{llcccr}
\hline & & \multicolumn{3}{c}{ Temperature $\left({ }^{\circ} \mathrm{C}\right)$} & \\
\cline { 3 - 5 } Yr & Month & Maximum & Minimum & Mean & Rainfall $^{\mathrm{y}}(\mathrm{mm})$ \\
\hline 2007 & February & 22.4 & 7.9 & 15.3 & 5.3 \\
& March & 27.1 & 12.6 & 19.5 & 15.7 \\
& April & 27.9 & 13.4 & 20.7 & 92.7 \\
& May & 31.4 & 16.7 & 24.0 & 0.0 \\
& June & 30.9 & 20.3 & 25.2 & 216.4 \\
& Mean/total & 28.3 & 14.1 & 21.1 & 69.6 \\
& & & & 18.1 & 86.6 \\
& February & 25.1 & 11.5 & 18.7 & 0.8 \\
& March & 24.9 & 12.4 & 20.5 & 61.5 \\
& April & 27.7 & 17.7 & 24.6 & 218.4 \\
\hline
\end{tabular}

${ }^{\mathrm{z}}$ Weather data obtained from Florida Automated Weather Network (FAWN) from University of Florida/ IFAS, Gulf Coast Research and Education Center in Balm, FL.

${ }^{y}$ UF/IFAS (University of Florida/Institute of Food and Agriculture Science) $34 \mathrm{~kg} \cdot \mathrm{ha}^{-1} \mathrm{~N}$ supplemental fertilizer application is allowed after a leaching rain defined as $76 \mathrm{~mm}$ in $3 \mathrm{~d}$ or $102 \mathrm{~mm}$ in $7 \mathrm{~d}$ for tomatoes (Olson et al., 2010). Because no qualifying leaching rain event occurred in either year, no supplemental $\mathrm{N}$ fertilizer was needed.

$\mathrm{N}=$ nitrogen

occurred in either year, no supplemental $\mathrm{N}$ fertilizer was recommended. During an El Niño-Southern Oscillation phase, the rainfall distribution and leaching rain events $(76 \mathrm{~mm}$ in $3 \mathrm{~d}$ or $102 \mathrm{~mm}$ in $7 \mathrm{~d}$ ) occurrences during the spring tomato-growing seasons using long-term weather records in the areas indicated low probability of leaching rain (Fraisse et al., 2010).

Water table depth. Water table depths in the monitoring wells fluctuated between 36 to 50 and 40 to $50 \mathrm{~cm}$ in 2007 and 2008, respectively. These fluctuations corresponded to higher water tables for plant establishment (first 4 weeks after planting) and as result of rainfall events in April $(92.7 \mathrm{~mm})$ and June $(102.4 \mathrm{~mm}) 2007$ and February $(69.6 \mathrm{~mm})$, March ( $86.6 \mathrm{~mm})$, and June $(61.5 \mathrm{~mm}) 2008$ (Table 1). Rainfall during the months noted previously were higher than normal, but none of the individual rainfall events exceeded the leaching rainfall rule; thus, soil $\mathrm{N}$ should not have been reduced below levels required by the crop and therefore no supplemental fertilizer was recommended (Olson et al., 2010). Overall, the water table depths recorded every $15 \mathrm{~d}$ indicated minimum fluctuation among treatments (data not shown); however, we cannot eliminate the possibility that water table depths were not elevated in response to rainfall between measurement dates.

Plant nutritional status response to nitrogen rates. Because the year-by- $\mathrm{N}$ rate interactions were significant for petiole $\mathrm{NO}_{3}-\mathrm{N}$ on most sampling dates in 2007 or $2008(P \leq 0.05)$, data were analyzed by year. Nitrate concentrations of petiole sap $\mathrm{NO}_{3}-\mathrm{N}$ (Fig. 1A-B) decreased over time in both years, following a typical pattern observed in seepage-irrigated tomatoes (Ozores-Hampton et al., 2007). Petiole $\mathrm{NO}_{3}-\mathrm{N}$ concentrations were greater in 2008 than those of the 2007 season. Tomato yield potential is typically determined around flower and fruit set $[3$ and 6 weeks after transplanting (WAT)] and fruit development (7 to 11 WAT) depending on the weather conditions (Hochmuth, 2009; Hochmuth et al.,
2009). Therefore, monitoring $\mathrm{N}$ tissue or petiole sap $\mathrm{NO}_{3}-\mathrm{N}$ concentrations becomes more critical during flower set and fruit development to obtained maximum marketable tomato yields (Hochmuth, 2009; Hochmuth et al., 2009).

In both 2007 and 2008, the petiole sap $\mathrm{NO}_{3}-\mathrm{N}$ values of the lowest $\mathrm{N}$ rate $\left(22 \mathrm{~kg} \cdot \mathrm{ha}^{-1}\right)$ fell below the UF/IFAS sufficiency values 7 WAT and the $67 \mathrm{~kg} \cdot \mathrm{ha}^{-1}$ falling below the sufficiency values after 9 WAT. Both lower N rates were significantly lower than all other $\mathrm{N}$ rates. In 2007, petiole sap $\mathrm{NO}_{3}-\mathrm{N}$ concentrations declined and fell below the sufficiency value for all rates below $202 \mathrm{~kg} \cdot \mathrm{ha}^{-1}$ after 11 WAT, and petiole sap $\mathrm{NO}_{3}-\mathrm{N}$ for all $\mathrm{N}$ rates ended the season at or below the sufficiency level (Fig. 1A). In 2008, sap $\mathrm{NO}_{3}-\mathrm{N}$ for all $\mathrm{N}$ rates lower than $403 \mathrm{~kg} \cdot \mathrm{ha}^{-1}$ were below the sufficiency level at the end of the season after 11 WAT and were significantly greater than the lower $\mathrm{N}$ rates (336 kg.ha ${ }^{-1}$ or less) (Fig. 1B). Similar results in Florida were obtained by Andersen et al. (1999) and Rhoads et al. (1996) who found that petiole sap $\mathrm{NO}_{3}-\mathrm{N}$ concentrations had a positive correlation with marketable yield and $\mathrm{N}$ rates before harvest. However, $\mathrm{NO}_{3}-\mathrm{N}$ selective electrodes or quick sap testing is less quantitative than standard laboratory tissue testing (Simonne and Hochmuth, 2010).

Yield responses to nitrogen rates. A significant year-by-N rate interaction occurred in both 2007 and 2008 for most of the yield components; therefore, data were analyzed by year. Overall, the first, second, and third harvests in 2007 accounted for $\approx 73 \%, 24 \%$, and $3 \%$ of total yield, respectively. This is typical of commercial yield distributions when the first harvest represents the majority of the harvest. The decision of whether to harvest a second or third time is based on the market prices of tomatoes at that time. Extra-large, total marketable fruits (all sizes categories combined), first and second harvest (97\% of the yields), and total marketable harvest (all categories and harvests combined) were analyzed using a quadratic plateau, quadratic, linear 


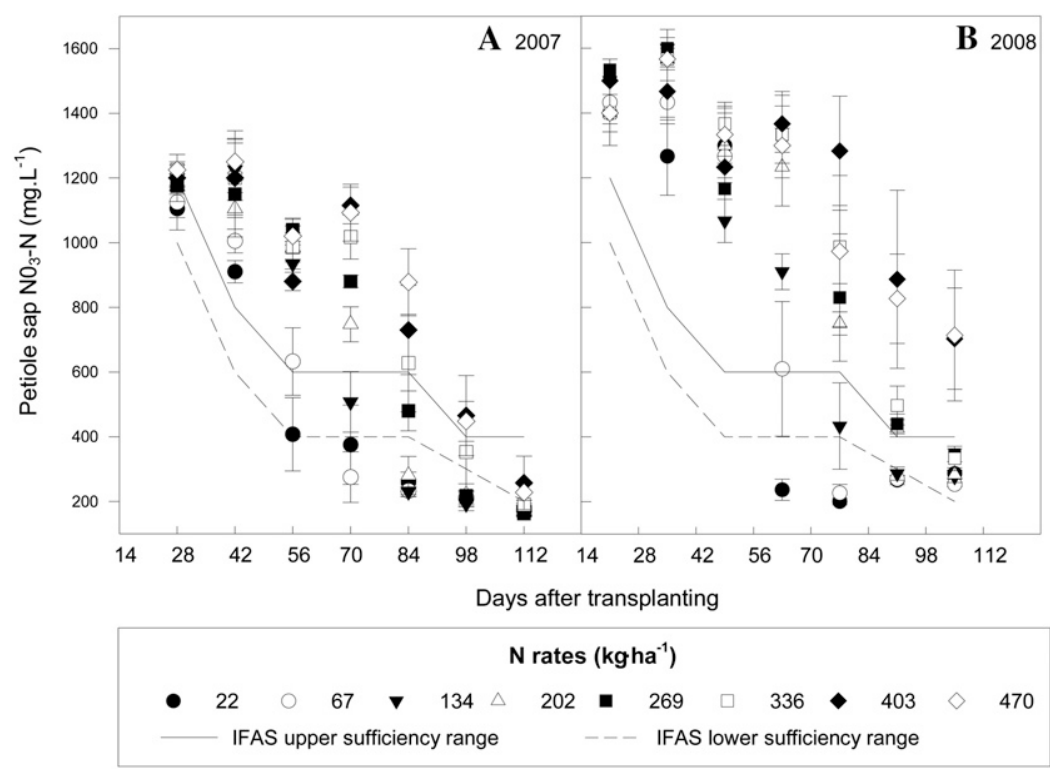

Fig. 1. Tomato ('Florida 47') $\mathrm{NO}_{3}-\mathrm{N}$ sap petiole concentration response to nitrogen $(\mathrm{N})$ rates during the spring of 2007 (A) and 2008 (B). Each data point is a mean of four samples, consisting of six most recently fully mature leaves beginning at first flower until second harvest and collected every 2 weeks. Bars denote SE.

plateau, and linear models (Table 2) in both years. The lowest MSE occurred with the quadratic plateau for first, first and second, and total marketable yield in both years, which identified the quadratic plateau as the best fit model. Hence, it was used for the interpretation of tomato yield response to $\mathrm{N}$ rates. The quadratic model overestimated the marketable yields and the linear plateau underestimated the marketable yields in both years. The linear model produced the poorest fits among model in both years.

The regression analysis of variance tables using the quadratic plateau model for total marketable first harvest yield showed a coefficient of determination $\left(R^{2}\right)$ of 0.39 and 0.37 in 2007 and 2008, respectively, and an $R^{2}$ for the total marketable first and second harvest yield was 0.73 and 0.75 , respectively (Fig. 2A-F). Coefficient of determination for total marketable yield (Harvests 1, 2, and 3 combined) were 0.74 and 0.78 in 2007 and 2008, respectively.

Calculated maximum total marketable yields at first, first and second, and total marketable harvest (all size categories and harvest combined) occurred at $\mathrm{N}$ rates of 93 and 92 , 165 and 303, and 172 and $298 \mathrm{~kg} \mathrm{~N} / \mathrm{ha}$ in 2007 and 2008, respectively (Table 2). Because $\approx 80 \%$ of the total marketable harvest was of extra-large fruit, the total maximum yield of extra-large fruit categories shared similar $\mathrm{N}$ rates of 86 and 97,135 and 265, and 136 and $277 \mathrm{~kg} \mathrm{~N} \cdot \mathrm{ha}^{-1}$ in 2007 and 2008, respectively. Only two studies with multiple $\mathrm{N}$ rates were done under seepage irrigation in Florida. Similarly, there were no differences in total marketable yield (8.7 to $16.4 \mathrm{Mg} \cdot \mathrm{ha}^{-1}$ ) of 'Sunny' tomato among $\mathrm{N}$ rates ranging from 179 to 450 $\mathrm{kg} \mathrm{N} / \mathrm{ha}$ (Hochmuth et al., 1989) and no response to $\mathrm{N}$ rates higher than $242 \mathrm{~kg} \mathrm{~N} / \mathrm{ha}$ was found on 'Walter' tomatoes with yields ranging from 9.2 to $21.6 \mathrm{Mg} \cdot \mathrm{ha}^{-1}$ (Everett, 1976). Two studies with seepage irrigation contrasting 224 to 312 and 384 to $450 \mathrm{~kg} \mathrm{~N} / \mathrm{ha}$ found that higher $\mathrm{N}$ rates increased large fruit yields at first and second harvest, but most of the yield differences were found in the third harvest and total marketable harvest (Ozores-Hampton et al., 2006).

Furthermore, maximum marketable yields were found with $\mathrm{N}$ rates lower (2007) and greater (2008) than the UF/IFAS-recommended rate of $224 \mathrm{~kg} \mathrm{~N} / \mathrm{ha}$. The $2007 \mathrm{~N}$ rate of 172 $\mathrm{kg} \mathrm{N} /$ ha was sufficient to produce the highest yields, although it was lower than $224 \mathrm{~kg} \mathrm{~N} / \mathrm{ha}$ UF/IFAS-recommended rate. Spring 2007 probably had better weather conditions for tomato growth and fruit set possibly because the major portion of the rainfall was at the end of the growing season (Table 1). In 2008, applying $298 \mathrm{~kg} \mathrm{~N} /$ ha yielded an estimated 86.4 Mg.ha ${ }^{-1}$ or $2.4 \mathrm{Mg} \cdot \mathrm{ha}^{-1}$ more than produced by an $\mathrm{N}$ rate of $224 \mathrm{~kg} \mathrm{~N} /$ ha (Table 2). Based on the total maximum marketable yields from Table 2, the $\mathrm{N}$ use efficiency (NUE) of tomato production per unit of applied $\mathrm{N}$ was 581.4 and $288.6 \mathrm{~kg} \cdot \mathrm{kg}^{-1}$ (kilograms yield per kilogram $\mathrm{N}$ applied) for 2007 and 2008, respectively. The differences in NUE could be explained by higher rainfall $(156 \mathrm{~mm})$ in first 8 WAT in 2008 during open flowers and fruit set together with and higher incidence of bacterial spot resulting in lower yields as a result of a lower plant biomass and higher $\mathrm{N}$ fertilizer rates requirements. Although $\mathrm{N}$ leaching below the root zone was not measured in this study, it may be likely that a substantial amount of $\mathrm{N}$ was leached from the beds in 2008. The leaching rain rule was designed to determine conditions requiring the application of additional $\mathrm{N}$ fertilizers. The lower $\mathrm{N}$ requirement in $2007\left(172 \mathrm{~kg} \cdot \mathrm{ha}^{-1}\right)$ suggests that rainfall did not leach enough fertilizer $\mathrm{N}$ to require application of additional fertilizer during the season and would explain the higher NUE. However, the higher cumulative rainfall early in the spring season of 2008 (Table 1) can explain the higher $\mathrm{N}$ requirement $\left(298 \mathrm{~kg} \cdot \mathrm{ha}^{-1}\right)$ for maximum yield suggesting higher rainfall accumulations early in the season may reduce soil $\mathrm{N}$ at a time of higher plant $\mathrm{N}$ demand and has greater impact on determining the need for supplemental fertilizer $\mathrm{N}$ applications. Leaf $\mathrm{NO}_{3}-\mathrm{N}$ sap analysis for 2008 presented earlier would indicate that only the lowest two $\mathrm{N}$ rates were insufficient for maximum production. However, Parks et al. (2012) suggested that leaf sap analysis by ion selective electrodes does not accurately represent plant $\mathrm{N}$ status as a result of higher $\mathrm{NO}_{3}-\mathrm{N}$ measurements that can be variable and larger than tissue analysis measurements. The high bias in values obtained by $\mathrm{NO}_{3}-\mathrm{N}$ selective electrodes is attributed to interference by plant organic compounds (Jackson, 1980), ions such as chloride (Sah, 1994), and high salt concentration on $\mathrm{NO}_{3}$ ion activity (Di Gioia et al., 2010). Therefore, the leaf sap values obtained in 2008 may have overestimated plant $\mathrm{N}$ status and clearly did not correspond to improved yields compared with 2007 fruit yields.

Postharvest quality. There were no differences in ripening rates as a result of $\mathrm{N}$ rate. Time to reach table-ripe stage was $12 \mathrm{~d}$ for tomatoes from both harvests and seasons (data not shown). The effect of $\mathrm{N}$ rates on table-ripe tomato SCC, TTA, or $\mathrm{pH}$ was not significant in either year for the first harvest $(P=0.17$, $0.32,0.38$ for 2007 and $0.89,0.80,0.95$ for 2008 , respectively) (data not shown). Mean values for pulp composition from the first harvest were SSC: 4.23 to 3.63 and 4.50 to $3.70{ }^{\circ} \mathrm{Brix}$; TTA: 0.42 to 0.33 and 0.50 to $0.36 \mathrm{mEq} / 100 \mathrm{~g}$ juice; and $\mathrm{pH}: 4.57$ to 4.49 and 4.53 to 4.44 for the 2007 and 2008 seasons, respectively. Results for these variables from the second harvests for both seasons, however, were inconsistent. Although SSC decreased with increased $\mathrm{N}$ rate (from greater than $5.0^{\circ}$ Brix to $4.0^{\circ} \mathrm{Brix}$ ), TTA had linear effects for the second harvests for the 2007 and 2008 seasons in response to $\mathrm{N}$ rates, ranging from 0.31 to $0.57 \mathrm{mEq} / 100 \mathrm{~g}$ juice. For 2007, TTA increased as N rate increased; for 2008, TTA had a higher value but was more variable. A negative linear response was found for pulp $\mathrm{pH}$ at the second harvest for 2007, but it was not significant for 2008 with value from both years ranging from 4.61 to 4.43. The values obtained for SSC, TTA, and $\mathrm{pH}$ were within the ranges of typical values that have been previously reported for several tomato cultivars (Maul et al., 2000). Although there were significant responses in SSC and TTA for the second harvests for both seasons, these differences were numerically small and suggest that actual tomato flavor was unaffected by $\mathrm{N}$ rate within the broad range used in this study. Finally, the lack of any interaction between $\mathrm{N}$ rate and tomato ripening rate (e.g., fruit firmness) supports the contention that tomatoes grown with higher $\mathrm{N}$ rates are not inherently softer than those grown under lower $\mathrm{N}$ rates. 


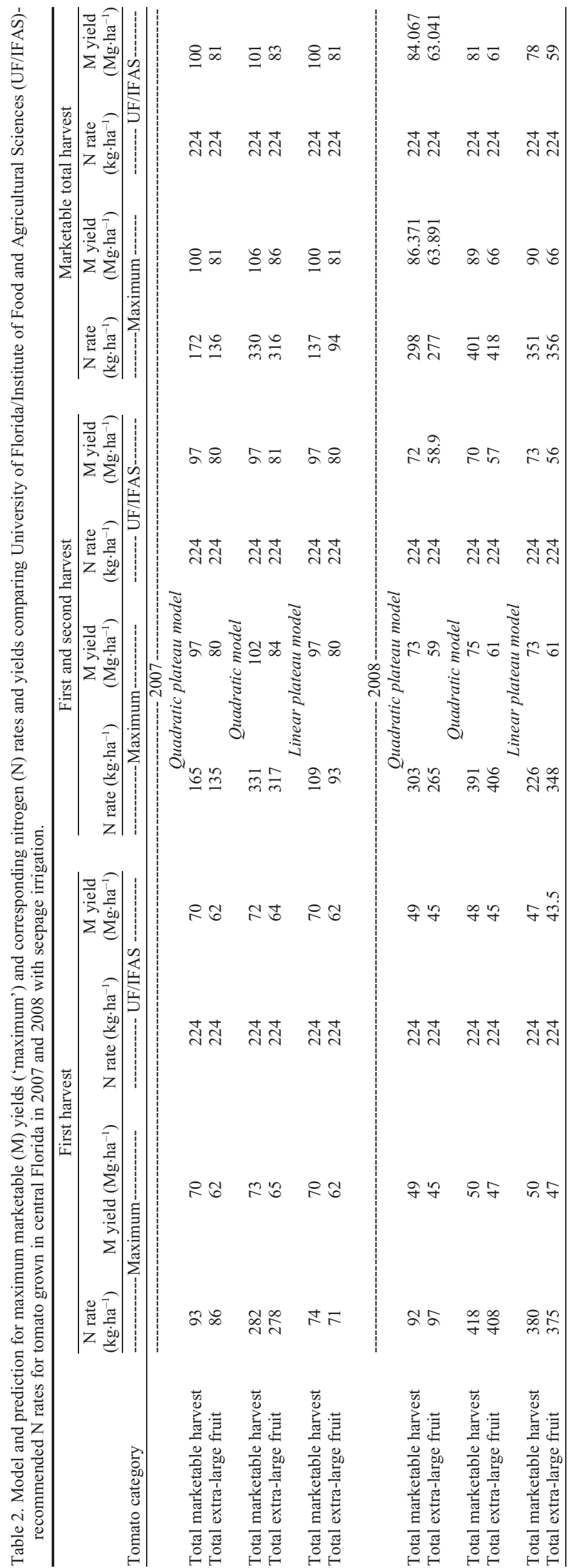

Economic implications. In 2007, the N rate that maximized total marketable yield was $172 \mathrm{~kg} \cdot \mathrm{ha}^{-1}, 23 \%$ lower than the UF/ IFAS-recommended rate of $224 \mathrm{~kg} \cdot \mathrm{ha}^{-1}$. Given the functional form of the yield response curve (quadratic plateau), the additional $52 \mathrm{~kg} \cdot \mathrm{ha}^{-1}$ of $\mathrm{N}$ fertilizer did not produce higher tomato yields. In 2008, growing conditions changed and the predicted $\mathrm{N}$ rate that maximized tomato marketable yields was $298 \mathrm{~kg} \cdot \mathrm{ha}^{-1}$. The $75 \mathrm{~kg} \cdot \mathrm{ha}^{-1}$ of additional $\mathrm{N}$ was predicted to increase tomato yields by more than $2.5 \mathrm{Mg}$ above the predicted yield for the UF/IFAS recommendation of $224 \mathrm{~kg} \cdot \mathrm{ha}^{-1}$ because the plateau started at an $\mathrm{N}$ rate greater than the recommended one.

Nitrogen rates that maximized production in both 2007 and 2008 were nearly identical to the $\mathrm{N}$ rates that maximized grower profits. The ratio of $\mathrm{N}$ and tomato prices for market Scenario 1 was extremely small (0.001) and the difference between an $\mathrm{N}$ rate to achieve maximum production and the $\mathrm{N}$ rate that maximized income was only $1.3 \mathrm{~kg} \cdot \mathrm{ha}^{-1}$. Furthermore, a significant change in market conditions did little to change the profit maximizing level of $\mathrm{N}$. Doubling $\mathrm{N}$ prices to $\$ 1.76 / \mathrm{kg}$ and reducing tomato prices by $50 \%$ to $\$ 441 / \mathrm{Mg}$ may have quadrupled the price ratio, but the real increase was small (from 0.001 to 0.004) and the economic optimal $\mathrm{N}$ rate was reduced by only 3.3 $\mathrm{kg} \cdot \mathrm{ha}^{-1}$.

The financial consequences of restricting $\mathrm{N}$ rates to a predetermined UF/IFAS rate are mixed and depend on the particular growing season. If growing conditions are such that $\mathrm{N}$ rates above the UF/IFAS recommendation produce more marketable yield, then the grower's economic losses are the value of the additional yield less the cost of added fertilizer and the unit costs associated with harvesting and packing more cartons of tomatoes. In 2008, $298 \mathrm{~kg} \cdot \mathrm{ha}^{-1}$ of $\mathrm{N}$ would have produced $2.5 \mathrm{Mg}$ of additional tomatoes. Grower income increased by $\$ 2174 /$ ha with a tomato price of $\$ 882 / \mathrm{Mg}$ and $\mathrm{N}$ cost of $\$ 0.88 / \mathrm{kg}$. Growers still would have gained nearly $\$ 1000 /$ ha under Scenario 2 conditions where $\mathrm{N}$ costs doubled and tomato value was reduced by half. In 2007, growing conditions were such that $\mathrm{N}$ rates over $224 \mathrm{~kg} \cdot \mathrm{ha}^{-1}$ did not produce any additional yield. In fact, a grower could have applied $76 \mathrm{~kg}$ less N/ha and produced the same volume of tomatoes. Consequently, grower cost for $\mathrm{N}$ was $\$ 67$ and $\$ 137 /$ ha higher under Scenarios 1 and 2, respectively.

Growers make their fertilization decisions without knowledge of final growing conditions and final market prices. In 2008, the amount of $\mathrm{N}$ required for maximum production would have justified $\mathrm{N}$ rates $100 \mathrm{~kg} \cdot \mathrm{ha}^{-1}$ above the UF/IFAS-recommended rate and would have been economically justified even with higher fertilizer costs. When prices warrant second and third harvests, tomato growers need to be able to capitalize with adequate available yields (Ozores-Hampton et al., 2006). Even under pessimistic economic 


\section{A First Harvest} 2007

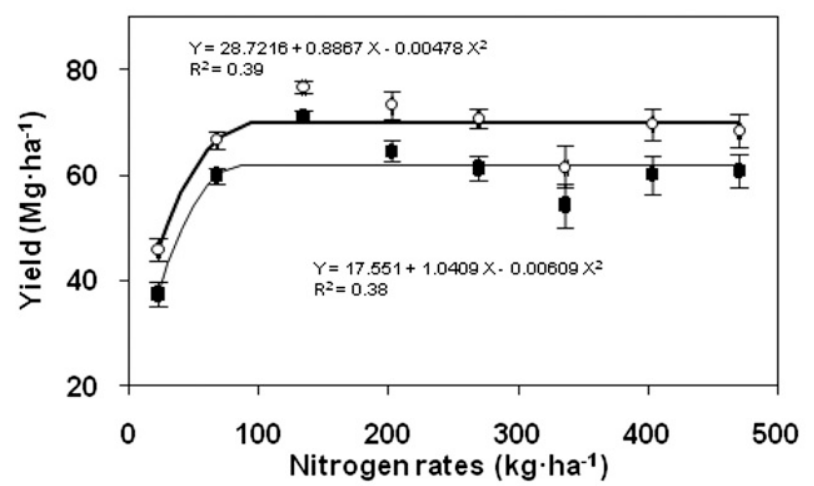

\section{B First and Second Harvest} 2007

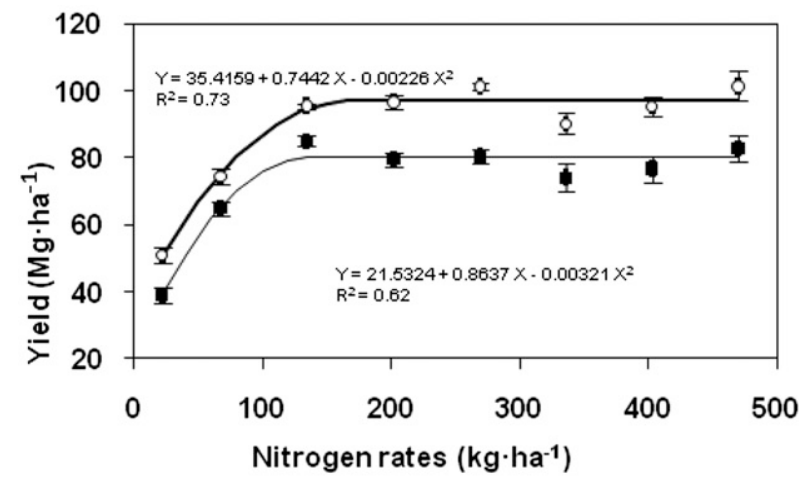

\section{First, Second and Third} Harvest 2007

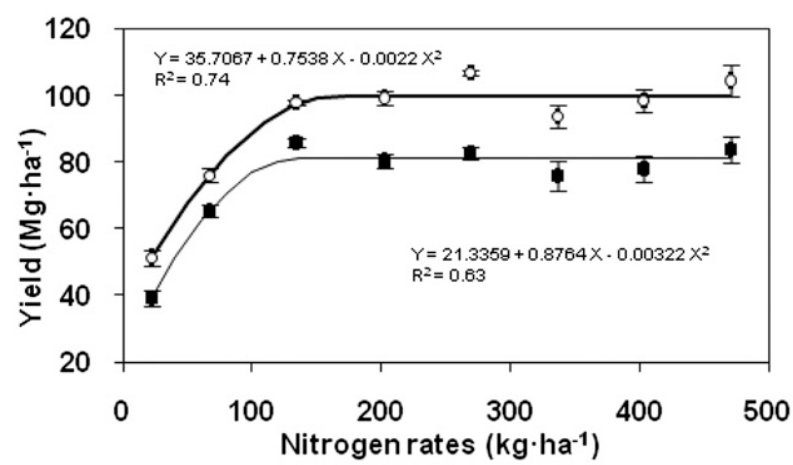

D First Harvest 2008

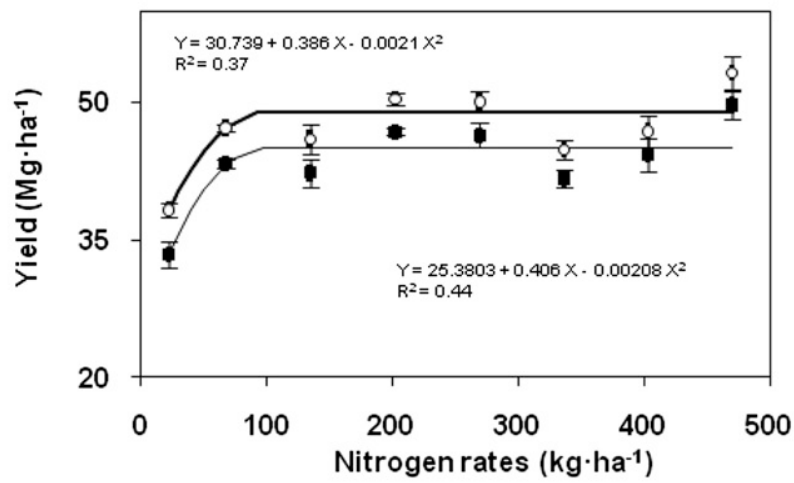

E First and Second Harvest 2008

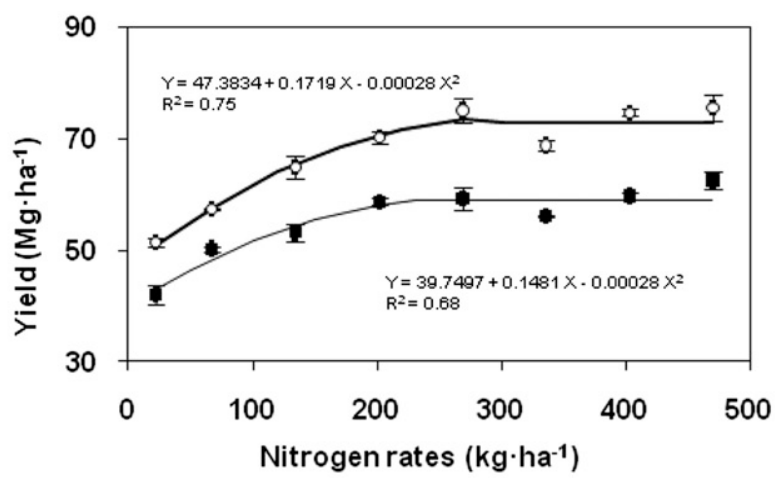

F First, Second and Third Harvest 2008

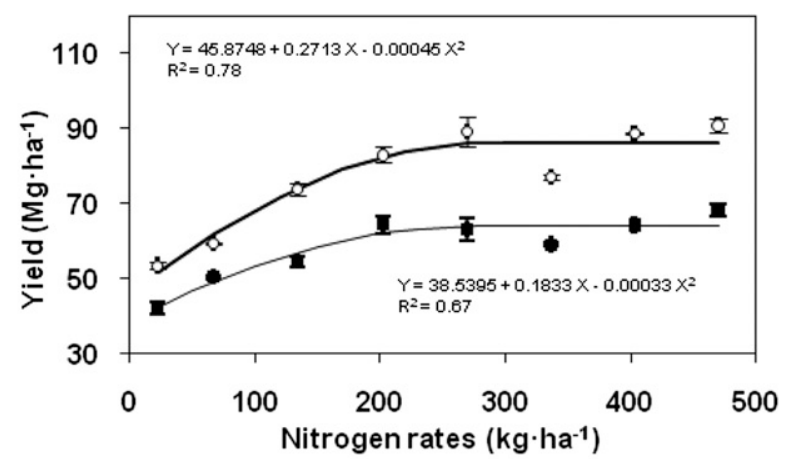

- Total marketable

Fig. 2. Tomato ('Florida 47') yield response to nitrogen (N) rates during the spring of 2007 and 2008 for the first harvest (A and D), first and second harvests combined ( $\mathbf{B}$ and $\mathbf{E}$ ), and all three harvests combined $(\mathbf{C}$ and $\mathbf{F})$, following a quadratic plateau model: $\mathrm{Y}=a+b \mathrm{X}+c \mathrm{X}^{2}$ if $\mathrm{X}<\mathrm{N}$ critical rate, $y=$ plateau yield if $\mathrm{X}>\mathrm{N}$ critical rate. Each data point is a mean of four replications consisting of marketable mature green and colored tomatoes graded in the field according to USDA specifications for extra-large $(5 \times 6)$, large $(6 \times 6)$, and medium $(6 \times 7)$ fruit categories. Bars denote SE.

conditions described by Scenario 2, the extra $\$ 992$ of profits gained in 2008 from $\mathrm{N}$ rates would have paid for seven tomato seasons of following the UF/IFAS-recommended $\mathrm{N}$ rate (Table 3; \$992/\$134).

In conclusion, results from two spring seepage-irrigated tomatoes indicated that 172 and $298 \mathrm{~kg} \cdot \mathrm{ha}^{-1}$ of $\mathrm{N}$ produced maximum marketable yields with three harvests. Essentially, postharvest fruit quality was unaffected by $\mathrm{N}$ rate. Fruit ripened normally, and slight differences in pulp SCC, TTA, and $\mathrm{pH}$ were not considered sufficient to affect fruit flavor to any perceptible extent. From a financial perspective, the high value of fresh-market tomatoes relative to the cost of $\mathrm{N}$ pushes growers to apply $\mathrm{N}$ at rates nearly $50 \%$ higher than what is being recommended by UF/IFAS.

Nutrient leaching may occur with any $\mathrm{N}$ rate used; however, more $\mathrm{N}$ applied to the soil at the beginning of the season increases the risk for a large amount of $\mathrm{N}$ loss. The social/ public costs associated with $\mathrm{N}$ losses from agricultural production to the environment (e.g., water quality remediation, loss water source, reduced recreational use) are substantial but must balance with the farmer's ability to produce economical yields. The insensitivity of "optimal" economic N rates to changes in $\mathrm{N}$ prices, however, suggests the strong possibility that growers could be convinced to shift to higher cost controlled-release fertilizers that have been shown to reduce $\mathrm{N}$ 
Table 3. Nitrogen $(\mathrm{N})$ rates that maximize yields versus maximize grower profit $(\pi)$ with financial comparisons and predicted yield under University of Florida/Institute of Food and Agricultural Sciences (UF/IFAS) N rates under two market scenarios for tomato grown in central Florida in 2007 and 2008 .

\begin{tabular}{|c|c|c|c|c|c|}
\hline \multirow[b]{3}{*}{ Parameter } & \multirow{3}{*}{$\begin{array}{l}\mathrm{N} \text { rates } \\
\left(\mathrm{kg} \cdot \mathrm{ha}^{-1}\right)\end{array}$} & \multirow{3}{*}{ 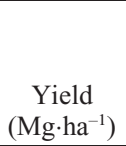 } & \multirow{3}{*}{ 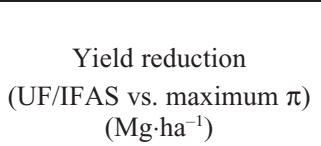 } & \multicolumn{2}{|c|}{$\begin{array}{l}\text { Value of yield reduction } \\
\text { (UF/IFAS vs. maximum } \pi \text { ) }\end{array}$} \\
\hline & & & & Scenario $1^{\mathrm{x}}$ & Scenario $2^{\mathrm{w}}$ \\
\hline & & & & \multicolumn{2}{|c|}{$(\$ /$ ha $)$} \\
\hline & & & . & & \\
\hline UF/IFAS & 224 & $83.87^{2}$ & - & & \\
\hline Maximum yield & 298.8 & 86.405 & 2.539 & - & - \\
\hline $\begin{array}{l}\text { Maximum } \pi \\
\quad(\text { Scenario } 1)\end{array}$ & 297.2 & 86.405 & 2.539 & $\$ 2,174$ & - \\
\hline $\begin{array}{l}\text { Maximum } \pi \\
\quad(\text { Scenario } 2)\end{array}$ & 393.0 & 86.397 & 2.531 & - & $\$ 992$ \\
\hline UF/IFAS & 224 & $100.571^{\mathrm{y}}$ & - & & \\
\hline Maximum yield & 172.1 & 100.571 & 0.0 & - & - \\
\hline $\begin{array}{l}\text { Maximum } \pi \\
\quad(\text { Scenario } 1)\end{array}$ & 171.9 & 100.571 & 0.0 & $(\$ 67)^{\mathrm{v}}$ & - \\
\hline $\begin{array}{l}\text { Maximum } \pi \\
\quad(\text { Scenario } 2)\end{array}$ & 171.2 & 100.570 & 0.001 & - & $(\$ 134)^{\mathrm{v}}$ \\
\hline
\end{tabular}

${ }^{2} \mathrm{~N}$ response equation shown in Figure 2F; $\mathrm{Y}=45.8748+0.2713(\mathrm{X})-0.00045\left(\mathrm{X}^{2}\right)$

${ }^{y} \mathrm{~N}$ response equation shown in Figure 2C. $\mathrm{Y}=35.7067+0.7538(\mathrm{X})-0.00220\left(\mathrm{X}^{2}\right)$.

${ }^{\mathrm{x}}$ Scenario 1.2008 market conditions; $\mathrm{N}$ cost $\$ 0.88 / \mathrm{kg}$; tomato price (net harvest and packing costs $\$ 882 /$ $\mathrm{Mg}$, or \$10/12.5-kg carton.

${ }^{w}$ Scenario 2 . Higher $\mathrm{N}$ costs, $2 \times$ increase to $\$ 1.76 / \mathrm{kg}$ and lower tomato price by $50 \%$ (net harvest and packing costs) to $\$ 441 / \mathrm{Mg}$, or $\$ 5 / 12.5-\mathrm{kg}$ carton

${ }^{v}$ Value of $76 \mathrm{~kg}$ of N-fertilizer; $(300 \mathrm{~kg}-224 \mathrm{~kg}) \cdot \mathrm{ha}^{-1}$.

leaching to the environment if the added costs is warranted by similar or increased yields or profits. Growers would have to be convinced that these products would sufficiently sustain the nutritional needs of their crop into the second and third harvests. In addition, the selection of an $\mathrm{N}$ rate should be accompanied by cultural practices that reduce the risk of off-site nutrient movement such as a cover crop establishment after the third harvest to trap residual nutrients.

\section{Literature Cited}

Andersen, P.C., F.M. Rhoads, S.M. Olson, and B.V. Brodbeck. 1999. Relationships of nitrogenous compounds in petiole sap of tomato to nitrogen fertilization and the value of these compounds as a predictor of yield. HortScience 34:254-258.

Black, C.A. 1993. Nutrient supplies and crop yields: Response curve. In: Soil fertility evaluation and control. CRC Press, Inc., Boca Raton, FL.

Cantliffe, D., P. Gilreath, D. Haman, C. Hutchinson, Y. Li, G. McAvoy, K. Migliaccio, T. Olczyk, S. Olson, D. Parmenter, B. Santos, S. Shukla, E. Simonne, C. Stanley, and A. Whidden. 2006. Review of nutrient management systems for Florida vegetable producers. Proc. Fla. State Hort. Soc. 119:240-248.

Di Gioia, F., E.H. Simonne, M. Gonnella, P Santamaria, A. Gazula, and Z. Sheppard. 2010. Assessment of ionic interferences to nitrate and potassium analyses with ionselective electrodes. Commun. Soil Sci. Plan. 41:1750-1768.

Everett, P.H. 1976. Effect of nitrogen and potassium rates on fruit yield and size of mulchgrown staked tomatoes. Proc. Fla. State Hort. Soc. 89:159-162.

FDACS. 2006. Water quality/quantity best management practice manual for Florida vegetable and agronomic crops. 26 Mar. 2011. <http://www. floridaagwaterpolicy.com/PDF/Bmps/Bmp_ VeggieAgroCrops2005.pdf>.
Florida Senate. 1999. Florida Water Restoration Act (TMDL bill) SB2282, Florida Statutes XXIX, ch.403.067. 10 Dec. 2010. <http://www. flsenate.gov/Statutes/index.cfm?App_mode= Display_Statute\&Search_String $=\& U R L=0400$ 0499/0403/Sections/0403.067.html>.

Fraisse, C.W., Z. Hu, and E.H. Simonne. 2010 Effect of El Niño Southern Oscillation (ENSO) on the number of leaching rain events in Florida and implications on nutrient management for tomato. HortTechnology 20:120-132.

Geraldson, C.M. and B. Whisenant. 1993. An opinion on the gradient concept of nutrition. Proc. Florida State Hort. Soc. 106:201-202.

Hochmuth, G. 2009. Plant petiole sap-testing for vegetable crops. Univ. Florida, IFAS, EDIS CIR 1144. 26 Nov. 2011. <http://edis.ifas.ufl edu/pdffiles/CV/CV00400.pdf $>$.

Hochmuth, G. and K. Cordasco. 2008. A summary of $\mathrm{N}, \mathrm{P}$, and $\mathrm{K}$ research with tomato in Florida. Univ. Florida, IFAS, EDIS publ. HS 759. 18 Aug. 2011. <http://edis.ifas.ufl.edu/cv236>.

Hochmuth, G., E. Hanlon, P. Gilreath, and K. Shuler. programs for subsurface-irrigated tomatoes. Proc. Florida. State Hort. Soc. 102:351-354.

Hochmuth, G., D. Maynard, C. Vavrina, E. Hanlon, and E. Simonne. 2009. Plant tissue analysis and interpretation for vegetable crops in Florida. Univ. Florida, IFAS, EDIS publ. HS 964. 26 Nov. 2011. <http://edis.ifas.ufl.edu/EP081>.

Jackson, R.K. 1980. Avoiding interferences and problems in the determination of nitrate - comparison of 2 methods - Orion specific ion electrode and the cadmium column. Commun. Soil Sci. Plan. 11:127-134.

Maul, F., S.A. Sargent, C.A. Sims, E.A. Baldwin, M.O. Balaban, and D.J. Huber. 2000. Tomato flavor and aroma quality as affected by storage temperature. J. Food Sci. 65:1218-1237.

NASS. 2009. National Agricultural Statistics Service. 19 Apr. 2011. <http://www.nass.usda.gov/>.

Olson, S.M., W.M. Stall, G.E. Vallad, S.E. Webb, S.A. Smith, E.H. Simonne, E. McAvoy, and B.M. Santos. 2010. Tomato production in Florida, p. 295-316. In: Olson, S.M. and B. Bielinski 1989. Field evaluations of nitrogen fertilization (eds.). 2010-2011 Vegetable production handbook for Florida. Vance Publishing, Lenexa, KS

Ozores-Hampton, M., E. Simonne, P. Gilreath, S. Sargent, D.C. McClure, T. Wilkes, E. McAvoy, P. Stansly, S. Shukla, P. Roberts, F. Roka, T. Obreza, K. Cushman, and D. Parmenter. 2007. Effect of nitrogen rate on yield of tomato grown with seepage irrigation and reclaimed water. Proc. Florida State Hort. Soc. 120:184-188.

Ozores-Hampton, M.P., E.J. McAvoy, M. Lamberts, and D. Sui. 2010. A survey of the effectiveness of current methods used for the freeze protection of vegetables in South Florida. Proc. Florida State Hort. Soc. 123:128-133.

Ozores-Hampton, M.P., E. Simonne, E. McAvoy, P. Stansly, S. Shukla, P. Roberts, F. Roka, T. Obreza, K. Cushman, P. Gilreath, and D. Parmenter. 2006. Nitrogen BMP efforts with tomato production in Florida: Update for 2005-2006 season. Proc. Florida State Hort. Soc. 119:284-288.

Parks, S.E., D.E. Irving, and P.J. Milham. 2012. A critical evaluation of on-farm rapid tests for measuring nitrate in leafy vegetables. Sci. Hort. 134:1-6.

Rhoads, F.M., S.M. Olson, G.J. Hochmuth, and E.A. Hanlon. 1996. Yield and petiole-sap nitrate levels of tomato with $\mathrm{N}$ rates applied preplant or fertigated. Proc. Soil Crop Sci. Soc. Fla. 55:9-12.

Sah, R.N. 1994. Nitrate-nitrogen determination-A critical-review. Commun. Soil Sci. Plant Anal. 25:2841-2869.

Sato, S., K. Morgan, M.P. Ozores-Hampton, and E.H. Simonne. 2009. Spatial and temporal distributions in sandy soils with seepage irrigation: I. Ammonium and nitrate. Soil Sci. Soc. Amer. J. 73:1044-1052.

Simonne, E., C. Hutchinson, J. DeValerio, R Hochmuth, D. Treadwell, A. Wright, B. Santos, A. Whidden, G. McAvoy, X. Zhao, T. Olczyk, and A. Gazula. 2009. Current knowledge, gaps, and future needs for keeping water and nutrients in the root zone of vegetables grown in Florida. HortTechnology 20:143-152.

Simonne, E. and M. Ozores-Hampton. 2006. Challenges and opportunities for extension educators involved in best management practices. HortTechnology 16:403-407.

Simonne, E.H. and G.J. Hochmuth. 2010. Soil and fertilizer management for vegetable production in Florida, p. 3-15. In: Olson, S.M. and B. Santos (eds.). 2010-2011 Vegetable production guide for Florida. Vance Pub., Lenexa, KS

Simonne, E.H. and M. Ozores-Hampton. 2010. Water management for tomato. Florida Tomato Inst. Proc. PRO532. p. 34-37.

Smajstrla, A.G. 1997. Simple water level indicator for seepage irrigation. Univ. Florida, IFAS, EDIS Circ. 1188. 26 Mar. 2011. <http://edis.ifas. ufl.edu/AE085>.

Studstill, D., E.H. Simonne, R. Hochmuth, and T. Olczyk. 2006. Calibrating sap-testing meters. Univ. Florida, IFAS, EDIS Circ. 1074, 26 Mar. 2011. <http://edis.ifas.ufl.edu/HS328>.

U.S. Department of Agriculture. 1997. United States standards for grades of fresh tomatoes. Agr. Mktg. Serv. 26 Mar. 2011. <http://www. ams.usda.gov/standards/tomatfrh.pdfs.

U.S. Department of Agriculture. 2011. South and central Florida shipping point prices, Fruit \& Vegetable Market News Agr. Mktg. Serv. 29 Nov. 2011. <http://marketnews.usda.gov/portal/fv>.

U.S. Environmental Protection Agency. 2010. Clean Water Act. 10 Dec. 2010. <http://cfpub.epa. gov/npdes/cwa.cfm?program_id=45>.

Van Sickle, J.J. 2011. Cost of production of tomatoes in southwest Florida. 29 Nov. 2011. <http:// www.fred.ifas.ufl.edu/iatpc/files/SWTomato09. pdf $>$. 